\title{
Prolactin upregulates sphingosine kinase-1 expression and activity in the human breast cancer cell line MCF7 and triggers enhanced proliferation and migration
}

\author{
Frauke Döll ${ }^{1,2}$, Josef Pfeilschifter ${ }^{1}$ and Andrea Huwiler ${ }^{1,2}$ \\ ${ }^{1}$ Pharmazentrum frankfurt/ZAFES, Klinikum der J W Goethe-Universität, Theodor-Stern-Kai 7, D-60590 Frankfurt am Main, \\ Germany \\ ${ }^{2}$ Institut für Pharmakologie, Universität Bern, Friedbühlstrasse 49, CH-3010 Bern, Switzerland \\ (Requests for offprints should be addressed to A Huwiler; Email: huwiler@pki.unibe.ch)
}

\begin{abstract}
Sphingosine kinases (SK) catalyze the formation of sphingosine-1-phosphate (S1P) which plays a crucial role in cell growth and survival. Here, we show that prolactin (PRL) biphasically activates the SK-1, but not the SK-2 subtype, in the breast adenocarcinoma cell-line MCF7. A first peak occurs after minutes of stimulation and is followed by a second delayed activation after hours of stimulation. A similar biphasic effect on SK-1 activity is seen for $17 \beta$-estradiol $\left(E_{2}\right)$. The delayed activation of SK-1 derives from an upregulated mRNA and protein expression and is due to increased SK-1 promoter activity and mechanistically involves STAT5 activation as well as protein kinase $\mathrm{C}$ and the classical mitogen-activated protein kinases. Furthermore, glucocorticoids also block both hormone-induced SK-1 expression and activity. Functionally, long-term stimulation of MCF7 cells with PRL or $\mathrm{E}_{2}$ is well known to trigger increased cell proliferation and migration. Both hormone-induced cell responses critically involve SK-1 activation since the depletion of SK-1, but not SK-2, by siRNA transfection abolishes the hormone-induced cell proliferation and migration. In summary, our data show that $P R L$ and $E_{2}$ cause a pronounced delayed SK-1 activation which is due to increased gene transcription, and critically determines the capability of cells to grow and move. Thus, the SK-1 may represent a novel attractive target for anti-tumor therapy.
\end{abstract}

Endocrine-Related Cancer (2007) 14 325-335

\section{Introduction}

Sphingosine-1-phosphate (S1P) has turned out to be a bioactive lipid critically involved in various cell responses such as cell proliferation and differentiation, survival, and migration (Huwiler et al. 2000, Spiegel \& Milstien 2003, Hait et al. 2006). Although S1P may exert its effects via both intracellular and extracellular actions and targets, most of the so-far-described cellular responses triggered by $\mathrm{S} 1 \mathrm{P}$ are mediated through specific cell surface $\mathrm{S} 1 \mathrm{P}$ receptors, the $\mathrm{S}_{1} \mathrm{P}_{1-5}$ receptors, which belong to the class of G-protein-coupled receptors (Hla 2003).

$\mathrm{S} 1 \mathrm{P}$ is produced by sphingosine kinases (SKs) which can be activated by a variety of stimuli that couple either to receptor tyrosine kinases like the platelet-derived and epidermal growth factors (EGFs) or to various G-proteincoupled receptors (Alemany et al. 2000, Huwiler et al. 2006). To date, two SK subtypes have been cloned and partially characterized, SK-1 and SK-2 (Kohama et al. 1998, Liu et al. 2000). SK-1 was suggested to be involved in certain forms of cancer (Milstien \& Spiegel 2006), whereas SK-2 is speculated to contribute to immunological responses (Baumruker et al. 2005). Thus, overexpression of SK-1 leads to a transformed phenotype of NIH $3 \mathrm{~T} 3$ fibroblasts causing foci formation, colony growth in soft agar, and tumor formation in SCID mice (Xia et al. 2000). In addition, overexpression of SK-1 in MCF7 breast cancer cells causes enhanced proliferation, decreased apoptosis, and leads to larger tumors in nude mice in an estrogen-dependent manner (Nava et al. 2002, 
Sukocheva et al. 2003). Moreover, several tumor types showed an overexpression of SK-1 when compared with normal tissue (French et al. 2003). All these data strongly suggest a critical contribution of SK-1 in tumor development and growth.

The involvement of the mammogenic hormones prolactin (PRL) and $17 \beta$-estradiol $\left(\mathrm{E}_{2}\right)$ in normal mammary growth and development is well documented (Couse \& Korach 1999, Ormandy et al. 2003) and it has been suggested that these hormones may also contribute to the development and progression of breast cancer. $\mathrm{E}_{2}$ has been clearly defined as a mammary mitogen, and anti-estrogen therapy is the most successful treatment for patients with estrogen receptor $\alpha(\mathrm{ER} \alpha)$ positive breast tumors (Jordan 2004). But this therapy is restricted mainly because of a wide range of side effects of $E_{2}$ on bone, brain, cardiovascular, and other targeted tissues. Thus, understanding the signaling pathways that couple mammogenic hormones like PRL and $\mathrm{E}_{2}$ to a specific cellular function has become a primary focus of inquiry.

In this study, we investigated the contribution of SKs in PRL- and $\mathrm{E}_{2}$-mediated cell responses in the breast cancer cell line MCF7. We show for the first time that PRL is able to induce a prolonged SK-1, but not SK-2, enzymatic activity which is due to a stimulation of the SK-1 promoter activity causing increased mRNA and protein expression.

Furthermore, cell proliferation and migration, which are both triggered by PRL and $E_{2}$ and are critical for tumor development, strongly depend on SK-1 activity since cellular depletion of SK-1 by siRNA transfection abolishes both cell responses.

\section{Materials and methods}

\section{Chemicals}

$\left[{ }^{32} \mathrm{P}\right]$ ATP (specific activity, $>5000 \mathrm{Ci} / \mathrm{mmol}$ ) was from GE Health Care; dexamethasone, PRL, $E_{2}$, and 4,6-diamino-2-phenylindole (DAPI) were from Sigma-Aldrich Fine Chemicals; staurosporine and Ro 31-8220 were from Biomol, Hamburg, Germany; U0126 was from Merck Bioscience; monoclonal STAT5a/b antibody was from BD Biosciences, Heidelberg, Germany; siRNA of human STAT5 (sc29495) was from Santa Cruz, Heidelberg, Germany; OligofectAMINE and all cell culture nutrients were from Invitrogen.

\section{Cell culturing and siRNA transfections}

MCF7 cells were cultured as previously reported (Döll et al. 2005), and gene silencing of SKs was conducted exactly as described (Huwiler et al. 2006).

\section{Western blot analysis}

Confluent MCF7 were stimulated for the indicated time periods in phenol red-free Dulbecco's modified Eagle medium (DMEM) containing $0.1 \mathrm{mg} / \mathrm{ml}$ fatty acid-free BSA. Protein extracts were prepared exactly as previously described (Döll et al. 2005). About $30 \mu \mathrm{g}$ protein were separated by SDS-PAGE, transferred to nitrocellulose membrane, and Western blot analysis was performed as previously described using a polyclonal anti-peptide antibody against human SK-1 at a dilution of 1:2000 (Döll et al. 2005).

\section{Quantitative real-time PCR (TAQMAN)}

About $1.0 \mu \mathrm{g}$ total RNA isolated with TRIZOL reagent was used for reverse transcriptase-PCR (First strand synthesis kit, MBI) utilizing an oligo $(\mathrm{dT})_{18}$ primer for amplification. The real-time PCR was carried out in ABgene plates. Probes and primers for human SK-1, SK-2, and GAPDH were obtained from Applied Biosystems, Darmstadt Germany. The reporter dyes chosen were 6-FAM/Tamra and VIC/Tamra. The PCR buffer used in the experiments was from ABgene. After cDNA synthesis, $100 \mathrm{ng}$ was used for further analysis. The run was performed on the Applied Biosystems 7700 HT sequence detection system. The cycling conditions were as following: $95^{\circ} \mathrm{C}$ for $15 \mathrm{~min}(1 \mathrm{cycle}), 95^{\circ} \mathrm{C}$ for $15 \mathrm{~s}$, and $60^{\circ} \mathrm{C}$ for $1 \mathrm{~min}$ (40 cycles). SDS version 1.9.1 software (ABI Prism, Applied Biosystems) was used to analyze real-time and endpoint fluorescence.

\section{Promoter studies}

A 2217 bp fragment of the human SK-1 promoter was cloned by RT-PCR using the following primers: forward with a BglII side: $5^{\prime}$-gaagatctcaccaaagtccetcgctggag- $3^{\prime}$; reverse with a HindIII side: $5^{\prime}$-gggaagcttttctgggagaggatccetg- $3^{\prime}$. A 1053 bp SK-1 promoter fragment was cloned by RT-PCR using the same reverse primer and the forward primer: $5^{\prime}$-gaagatctgcttggctttccaatccegac-3'. A 619 bp SK-1 promoter fragment was cloned by RT-PCR using the same reverse primer and the forward primer: $5^{\prime}$-gaagatctgccttctagccagacgctag- $3^{\prime}$.

The promoter fragments were fused into the pGL3 basic luciferase reporter gene-containing vector (Promega). To measure SK-1 promoter activity, a luciferase reporter gene assay was performed exactly as previously described (Huwiler et al. 2006) using a Lumat LB9507 luminometer (Berthold Detection Systems, Pforzheim, Germany). 


\section{SK activity assay}

SK-1 activity was measured exactly as previously described (Döll et al. 2005, Huwiler et al. 2006). In brief, $30 \mu \mathrm{g}$ protein extracts and $10 \mu \mathrm{l}$ of $1 \mathrm{mM}$ sphingosine (dissolved in $1 \mathrm{mg} / \mathrm{ml}$ BSA) were mixed with SK-1 buffer (20 mM Tris, pH 7.4, $20 \%$ glycerol, $1 \mathrm{mM}$ mercaptoethanol, $1 \mathrm{mM}$ EDTA, $1 \mathrm{mM}$ sodium orthovanadate, $40 \mathrm{mM} \quad \beta$-glycerophosphate, $15 \mathrm{mM}$ $\mathrm{NaF}, 10 \mu \mathrm{g} / \mathrm{ml}$ leupeptin, $10 \mu \mathrm{g} / \mathrm{ml}$ aprotinin, $10 \mu \mathrm{g} /$ $\mathrm{ml}$ soybean trypsin inhibitor, $1 \mathrm{mM}$ phenylmethylsulfonyl fluoride) in a total volume of $190 \mu \mathrm{l}$. For SK-1 activity, $0.5 \%$ Triton X 100 was included to block SK2 activity (Liu et al. 2000). For SK-2 activity, $1 \mathrm{M} \mathrm{KCl}$ was included to block SK-1 activity (Liu et al. 2000). Reactions were started by addition of $10 \mu \mathrm{l}$ $\left[\gamma^{-32}\right.$ P]ATP $(10 \mu \mathrm{Ci}, 20 \mathrm{mM})$ in $200 \mathrm{mM} \mathrm{MgCl}_{2}$ and incubated for $15 \mathrm{~min}$ at $37^{\circ} \mathrm{C}$. Reactions were terminated by addition of $20 \mu \mathrm{l} 1 \mathrm{~N} \mathrm{HCl}$ followed by $800 \mu \mathrm{l}$ chloroform/methanol/HCl $(100 / 200 / 1$, v/v), $240 \mu \mathrm{l}$ chloroform and $240 \mu \mathrm{l}$ of $2 \mathrm{M} \mathrm{KCl}$ followed by vigorous vortexing. After phase separation, $50 \mu \mathrm{l}$ of the lipids in the organic lower phase were resolved by thin layer chromatography with 1-butanol/ethanol/ acetic acid/water (80:20:10:20, v/v). Spots corresponding to S1P were analyzed and quantified using an
Imaging System (Fujifilm Europe, Düssel dorf, Germany).

\section{Migration assay}

Chemotaxis was measured in Nunc cell culture inserts (polycarbonate membrane, $10 \mathrm{~mm}, 8.0 \mu \mathrm{m}$ pore size) exactly as described (Döll et al. 2005).

\section{Proliferation assay}

Transfected cells were starved for $24 \mathrm{~h}$ with serum-free DMEM. Proliferation of cells was assessed using $1 \mu \mathrm{Ci} / \mathrm{ml}\left[{ }^{3} \mathrm{H}\right]$ methyl-thymidine in the absence of serum for the last $4 \mathrm{~h}$ of stimulation. After $24 \mathrm{~h}$ of stimulation, cells were washed twice with PBS and incubated in 5\% trichloroacetic acid at $4{ }^{\circ} \mathrm{C}$ for $30 \mathrm{~min}$, and the DNA was solubilized in $0.5 \mathrm{M} \mathrm{NaOH}$ for $30 \mathrm{~min}$ at $37^{\circ} \mathrm{C}$. Finally, $\left[{ }^{3} \mathrm{H}\right]$ thymidine incorporation was determined in a $\beta$-counter.

\section{Statistical analysis}

Statistical analysis was performed by one-way ANOVA. For multiple comparisons with the same control group, the limit of significance was divided by the number of comparisons according to Bonferroni.
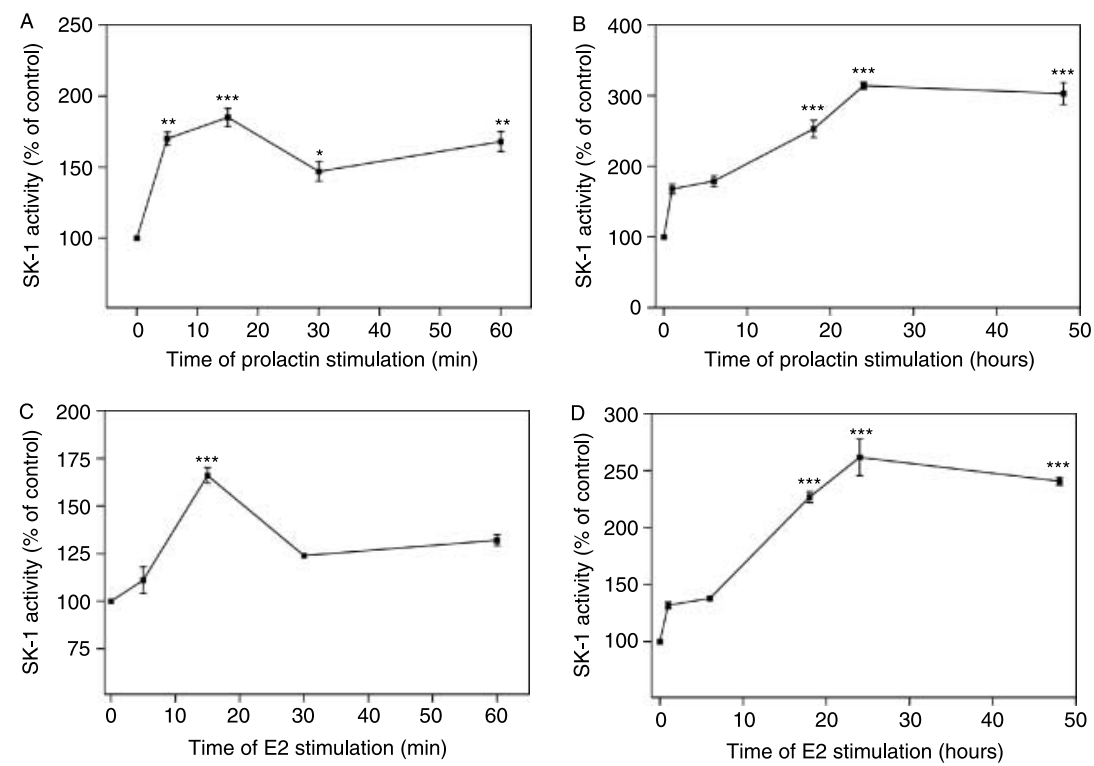

Figure 1 Time-dependent effects of prolactin and 17 $\beta$-estradiol on SK-1 activity in MCF7 cells. Confluent MCF7 cells were treated with $5 \mu \mathrm{g} / \mathrm{ml}$ prolactin (A and $B$ ) or $10 \mathrm{nM} 17 \beta-$ estradiol ( $C$ and $D)$ for short-term time periods (0-60 min; $A$ and $C$ ) or long-term time periods (1-48 h; B and D). Thereafter, cell lysates were taken for a SK-1 activity assay as described in the Materials and methods section. Data are expressed as percentage of control values and are means \pm S.D. $(n=3),{ }^{\star} P<0.05,{ }^{\star \star} P<0.01,{ }^{\star \star \star} P<0.001$ when compared with control values. 


\section{Results}

Stimulation of MCF7 cells with PRL leads to a biphasic increase in SK activity. A first peak of activation occurs after 15 min of stimulation (Fig. 1A) which declines again after $30 \mathrm{~min}$. A second peak of activity is observed after $1 \mathrm{~h}$ of stimulation reaching a plateau after $24 \mathrm{~h}$ and stays elevated for at least $48 \mathrm{~h}$ the latest time point measured (Fig. 1B). The delayed activation of SK-1 by PRL after $16 \mathrm{~h}$ is only slightly seen at $50 \mathrm{ng} / \mathrm{ml}$ of concentration but is more pronounced at $100 \mathrm{ng} / \mathrm{ml}$ and reaches maximal values at $1 \mu \mathrm{g} / \mathrm{ml}$ PRL (Fig. 2A). Another mammogenic hormone $\mathrm{E}_{2}$ is also able to induce a similar biphasic activation of SK-1 in MCF7 cells (Fig. 1C and D) which confirms previous data of Sukocheva et al. (2003, 2006). Dose-dependency experiments reveal a maximal effect on SK-1 activity after $16 \mathrm{~h}$ already at
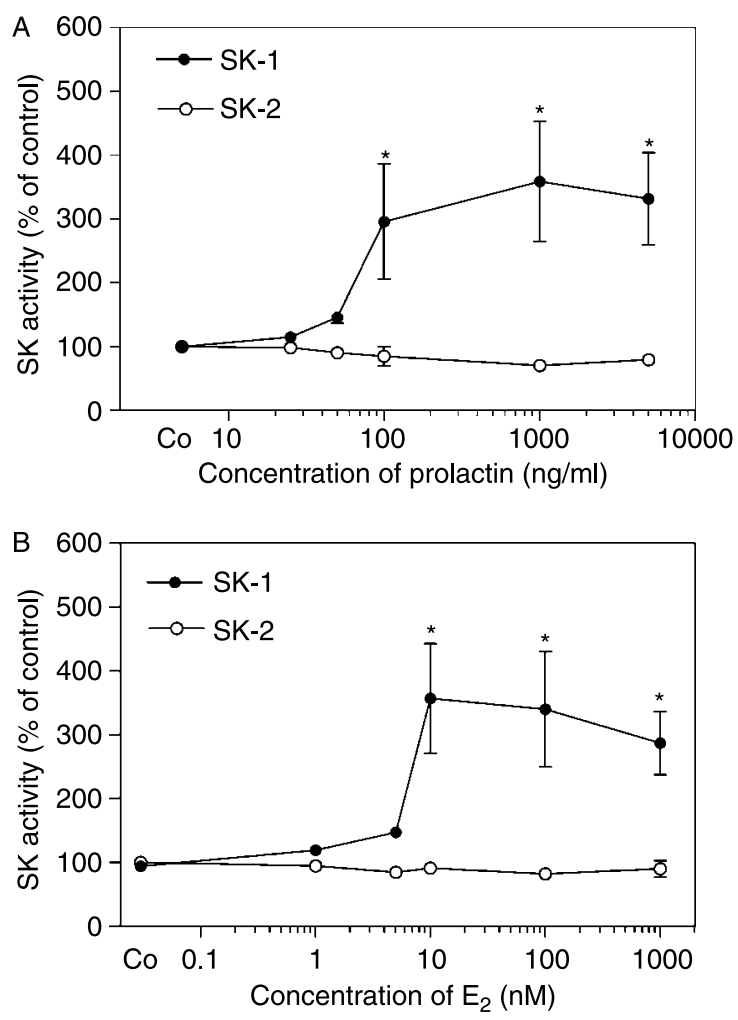

Figure 2 Dose-dependent effects of prolactin and $17 \beta$-estradiol on SK-1 and SK-2 activities in MCF7 cells. Confluent MCF7 cells were stimulated with the indicated concentrations of prolactin (A) or $17 \beta$-estradiol (B) for $16 \mathrm{~h}$. Thereafter, cell lysates were taken for an in vitro kinase assay for SK-1 activity (closed symbol) or SK-2 activity (open symbol) as described in the Materials and methods section. Results are expressed as percentage of control values and are means \pm s.D. $(n=3-6)$, ${ }^{\star} P<0.05$ when compared with control values. SK- 1 activity in control samples was at $13.9 \pm 1.9$ c.p.m./min per mg protein; SK-2 activity of control samples was at $2.15 \pm 0.44$ c.p.m. $/ \mathrm{min}$ per mg. the low concentration of $10 \mathrm{nM} \mathrm{E} \mathrm{E}_{2}$ (Fig. 2B). In contrast, SK-2 activity, which was assayed under conditions where SK-1 is inhibited, i.e. by including $1 \mathrm{M} \mathrm{KCl}$ (Liu et al. 2000), is not activated by PRL or $\mathrm{E}_{2}$ (Fig. 2A and B, open symbols).

To see whether the second delayed phase of SK activation depends on increased SK-1 protein expression, Western blot analyses were performed, using a specific antibody against SK-1 which was previously characterized (Döll et al. 2005, Huwiler et al. 2006).

As seen in Fig. 3A, PRL stimulation of MCF7 cells leads to a dose-dependent increased expression of the 44 and $51 \mathrm{kDa}$ form of SK-1 (Fig. 3A). Similarly, $\mathrm{E}_{2}$ also upregulates SK-1 protein expression (Fig. 3B). To further characterize whether the enhanced SK1 activity and protein expression is preceded by an enhanced mRNA expression, quantitative real-time PCR was performed. As shown in Fig. 3C, SK-1 mRNA expression is dose-dependently enhanced by PRL and also by $\mathrm{E}_{2}$. In contrast, SK-2 mRNA expression is rather downregulated by hormone treatment.

The increased mRNA expression of SK-1 is owing to increased gene transcription as shown by SK-1 promoter studies. To this end, a long (2217 bp) and two shorter (1053 and $691 \mathrm{bp}$ ) fragments of the human SK-1 promoter were cloned according to Nakade et al. (2003) and fused to a luciferase-containing vector. Transfection of MCF7 cells with these fragments followed by PRL or $E_{2}$ stimulation reveals that only the long $2217 \mathrm{bp}$ promoter fragment is able to increase luciferase activity, whereas the two shorter fragments are ineffective (Fig. 4).

To further document that the delayed activation of SK-1 by PRL and $\mathrm{E}_{2}$ is due to increased de novo protein synthesis, the general translation inhibitor cycloheximide (CHX) was applied. As seen in Fig. 5A, CHX completely abolishes the delayed activation of SK-1 by both PRL and $E_{2}$. In contrast, CHX has no reducing effect of the short-term PRL- or $\mathrm{E}_{2}$-stimulated SK-1 activity (Fig. 5B), whereas the MEK inhibitor U0126 completely abolishes the early SK-1 activation (Fig. 5B), confirming previous reports that the rapid activation of SK-1 requires the classical mitogen-activated protein kinase (MAPK) cascade.

The mechanisms of delayed SK-1 activation were further characterized. The MEK inhibitor U0126 not only suppresses the early effect of PRL on SK-1 activity (Fig. 5B), but also blocks the delayed effect (Fig. 6A). Similarly, the potent but unspecific protein kinase $\mathrm{C}$ (PKC) inhibitor staurosporine and the highly specific PKC inhibitor Ro 31-8220 completely abolish the effect of PRL on SK-1 activity (Fig. 6A). All these inhibitors that reduced SK-1 activity also 
A
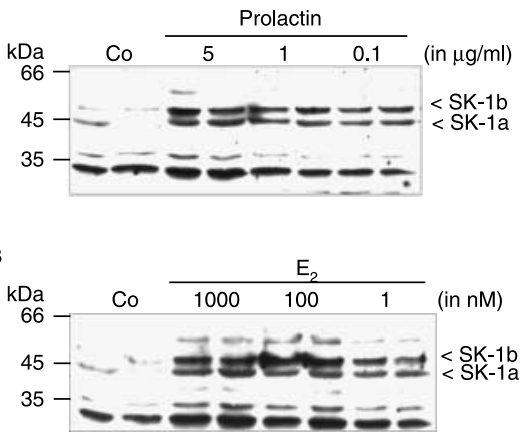

C

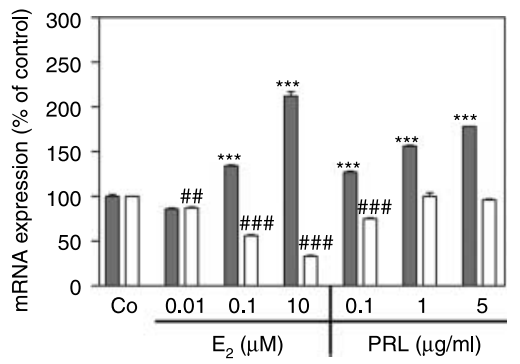

Figure 3 Effect of prolactin and 17 $\beta$-estradiol on SK-1 protein and mRNA expression in MCF7 cells. MCF7 cells were stimulated for $16 \mathrm{~h}$ with either vehicle (Co) or the indicated concentrations of prolactin (A) or $17 \beta$-estradiol $(B)$. Thereafter, cell extracts were separated by SDS-PAGE, transferred to a nitrocellulose membrane, and subjected to western blot analysis using a specific anti-SK-1 antibody at a dilution of 1:2000. Bands were visualized by using the ECL detection system. Data are representative of three independent experiments giving similar results. (C) Stimulated MCF7 cells were taken for RNA extraction and subjected to quantitative real-time PCR of hSK-1 (closed columns) or hSK-2 (open columns) as described in the Materials and methods section. Results are expressed as percentage of control values and are means \pm S.E.M. $(n=3),{ }^{\star \star \star} P<0.001$ when compared with the control hSK-1 values; ${ }^{\# \#} P<0.01$, ${ }^{\# \#} P<0.001$ when compared with the control hSK-2 values.

downregulated SK-1 mRNA expression (data not shown). Similarly, $\mathrm{E}_{2}$-stimulated delayed SK-1 activity also involves PKC and the classical MAPKs (Fig. 6B).

Furthermore, since PRL has previously been reported to activate the Janus kinase (JAK)-STAT pathway especially involving STAT5 (Liu et al. 1995, Hynes et al. 1997), the involvement of STAT5 in SK-1 activation was investigated by depleting STAT5 by siRNA transfection. As seen in Fig. 7A inset, the STAT5 siRNA completely blocks STAT5 protein expression. Under this STAT5-depleted condition, PRL-triggered delayed SK-1 activity is abolished, suggesting that STAT5 is a critical transcription factor involved in PRL-stimulated delayed SK-1 upregulation. In contrast, depletion of STAT5 has no effect on the acute activation of SK-1 (Fig. 7B).

Interestingly, the synthetic glucocorticoid dexamethasone also reduces both PRL- and $\mathrm{E}_{2}$-induced delayed SK-1 activity (Fig. 8) and mRNA expression (data not shown).

Increased proliferation and cell migration is not only characteristic for cancer cells but also normal breast epithelial cells are characterized by their ability to migrate and proliferate during the lactation cycle. To see whether SK-1 is involved in these cell responses, we depleted SK-1 from MCF7 cells by using the technique of siRNA transfection. As previously shown, transfection of MCF7 cells with siRNA targeted to SK-1 specifically reduced the expression of SK-1 without affecting SK-2 (Döll et al. 2005). For MCF7 cells, both PRL and $\mathrm{E}_{2}$ are well-established growth factors causing an increased $\left[{ }^{3} \mathrm{H}\right]$ thymidine incorporation into newly synthesized DNA (Fig. 9). However, when SK-1 was depleted from the cells, neither PRL nor $\mathrm{E}_{2}$ triggered cell proliferation anymore (Fig. 9), whereas neither a scrambled oligonucleotide nor siRNA of SK-2 affected the PRL- and $\mathrm{E}_{2}$-stimulated proliferation (Fig. 9).

Finally, we measured the migratory capacity of MCF7 cells upon PRL and $\mathrm{E}_{2}$ stimulation. As seen in Fig. 10,

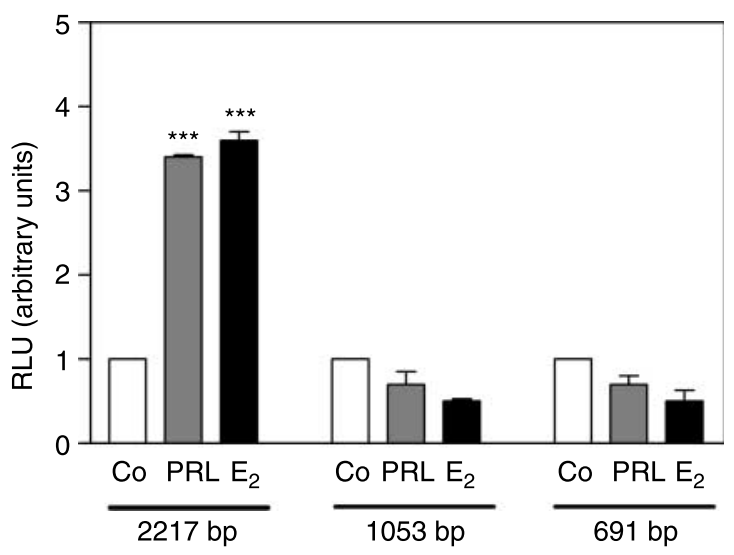

Figure 4 Effect of prolactin and $E_{2}$ on SK-1 promoter activity in MCF7 cells. Subconfluent MCF7 cells were co-transfected with the wild-type 2217 bp SK-1 promoter DNA, a 1053 bp fragment, or a $691 \mathrm{bp}$ fragment plus the plasmid coding for Renilla luciferase ( $p R L-C M V)$. After $24 \mathrm{~h}$ of transfection, cells were rendered serum-free and stimulated for $16 \mathrm{~h}$ with either vehicle (Co), prolactin (PRL, $5 \mu \mathrm{g} / \mathrm{ml}$ ), or $17 \beta$-estradiol $\left(E_{2}, 1 \mu \mathrm{M}\right)$. The ratio between beetle and Renilla luciferase activities was calculated and is depicted as relative luciferase activity (RLU). Data are means \pm S.E.M. $(n=3),{ }^{* *} P<0.001$ when compared with the vehicle-stimulated control value. 


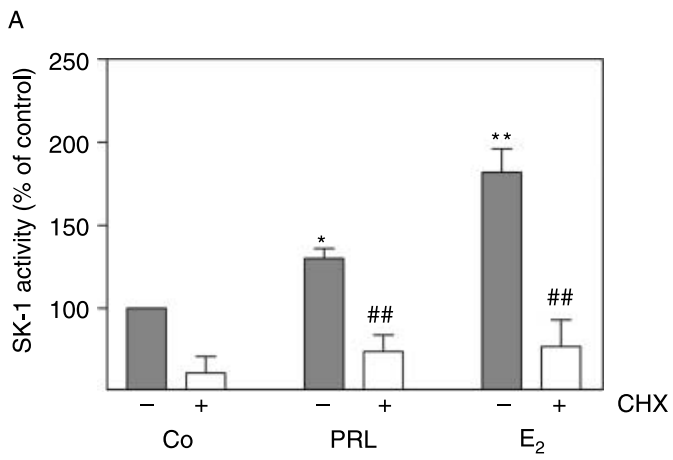

B

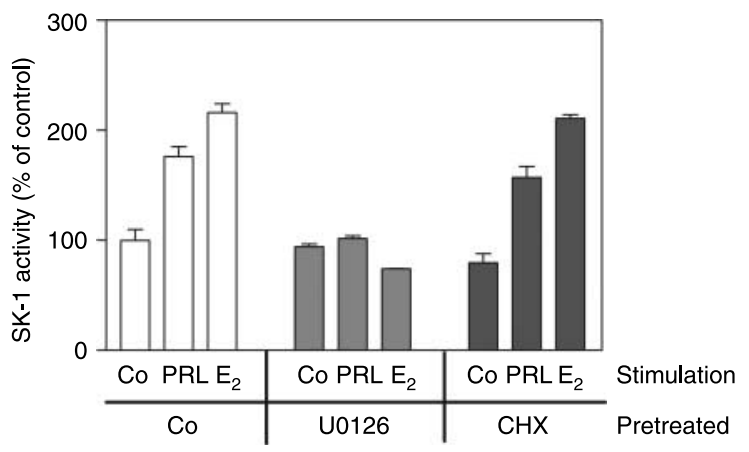

Figure 5 Effect of cycloheximide on prolactin- and $17 \beta$ estradiol-induced SK-1 activity in MCF7 cells. (A) Cells were stimulated for $24 \mathrm{~h}$ with either vehicle (Co), $5 \mu \mathrm{g} / \mathrm{ml}$ prolactin (PRL), or $10 \mathrm{nM} 17 \beta$-estradiol $\left(\mathrm{E}_{2}\right)$ in the absence $(-$, closed columns) or presence ( + , open columns) of $100 \mathrm{ng} / \mathrm{ml}$ cycloheximide ( $\mathrm{CHX})$. (B) Cells were pretreated for 20 min with either vehicle, U0126 $(20 \mu \mathrm{M})$, or cycloheximide (CHX, $100 \mathrm{ng} / \mathrm{ml}$ ) prior to stimulation for $15 \mathrm{~min}$ with $5 \mu \mathrm{g} / \mathrm{ml}$ prolactin (PRL) or $10 \mathrm{nM} 17 \beta$-estradiol $\left(E_{2}\right)$. Thereafter, cell lysates were taken for an SK-1 activity assay as described in the Materials and methods section. Results are expressed as percentage of control values and are means \pm s.D. $(n=3),{ }^{*} P<0.05$,

${ }^{\star \star} P<0.01,{ }^{\star \star \star} P<0.001$ considered statistically significant when compared with control values; ${ }^{\# \#} P<0.01$, ${ }^{\# \prime \#} P<0.001$, when compared with the stimulated values in the absence of $\mathrm{CHX}$.

PRL and $E_{2}$ triggered a pronounced increase of cell migration. This effect is significantly reduced when depleting cells of SK-1, but not when using scrambled siRNA oligonucleotides or siRNA of SK-2. Additionally, CHX treatment abolishes both the PRL and $\mathrm{E}_{2}$ effect on cell migration (Fig. 11A), whereas the depletion of STAT5 from cells only abrogates the PRL effect, but not the $\mathrm{E}_{2}$ effect on cell migration (Fig. 11B).

\section{Discussion}

In this study, we show for the first time that the mammogenic and lactogenic hormone PRL activates SK-1 in MCF7 breast cancer cells. PRL triggers a biphasic activation pattern of SK-1, i.e. a rapid and
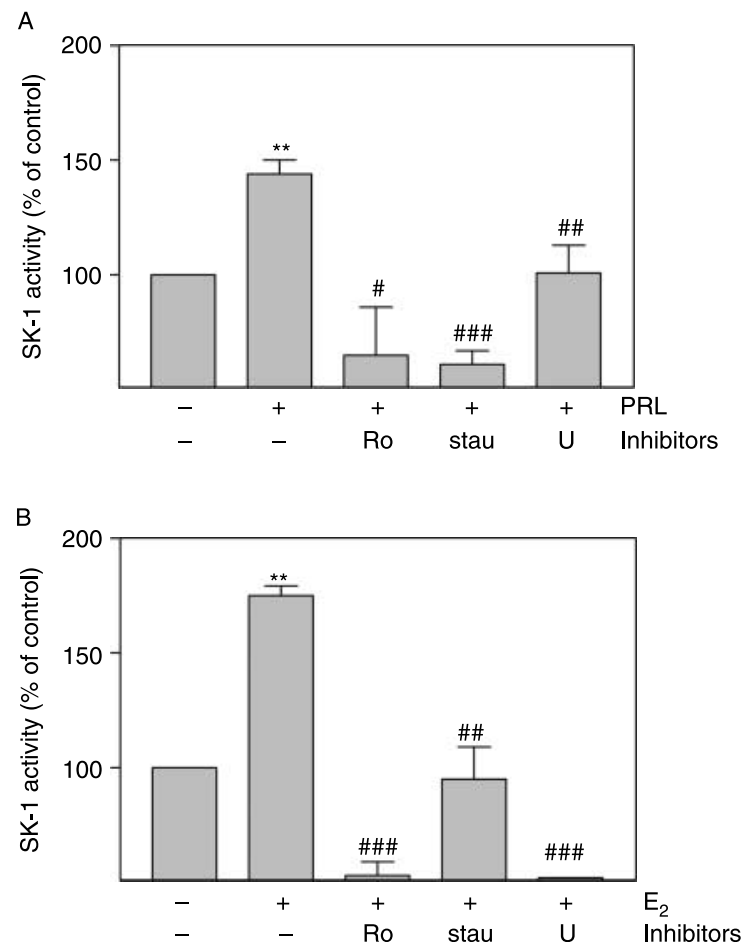

Figure 6 Effect of various inhibitors on prolactin- and estradiolinduced SK-1 activity in MCF7 cells. (A) MCF7 cells were pretreated for $20 \mathrm{~min}$ with either vehicle (-), Ro 31-8220 (Ro, $10 \mathrm{nM}$ ), staurosporine (stau, $10 \mathrm{nM})$, or $\mathrm{U} 0126(\mathrm{U}, 10 \mu \mathrm{M})$ prior to stimulation for $16 \mathrm{~h}$ with either vehicle $(-)$, prolactin (PRL, $5 \mu \mathrm{g} / \mathrm{ml} ; A)$, or $17 \beta$-estradiol $\left(E_{2}, 10 \mathrm{nM} ; B\right)$. Cell extracts were taken for an SK-1 activity assay as described in the Materials and methods section. Results are expressed as percentage of control values and are means \pm S.D. $(n=3),{ }^{* *} P<0.01$ when compared with unstimulated control values; ${ }^{\#} P<0.05$, ${ }^{\# \#} P<$ 0.01 , \#\#\# $P<0.001$ when compared with the PRL- or $E_{2}-$ stimulated values respectively.

transient first peak and a second more delayed peak of activity occurring after $20 \mathrm{~h}$ and lasting up to $48 \mathrm{~h}$.

PRL is one important hormone required for mammary gland differentiation promoting morphological development and milk protein production in the lactating gland. Recent evidence has risen that PRL also plays a role in breast cancer development and growth (Tworoger \& Hankinson 2006). In rodents, PRL shows a clear tumor-promoting efficiency as transgenic female mice overexpressing the PRL gene spontaneously develop mammary carcinomas (RoseHellekant et al. 2003), whereas in humans, the role of PRL in tumor formation and progression is less clear due to the failure of clinical trials evaluating the potential of functional PRL antagonists. Thus, although dopamine agonists (in vivo dopamine is the physiological negative regulator of PRL release from the anterior pituitary gland) drastically reduce circulating 


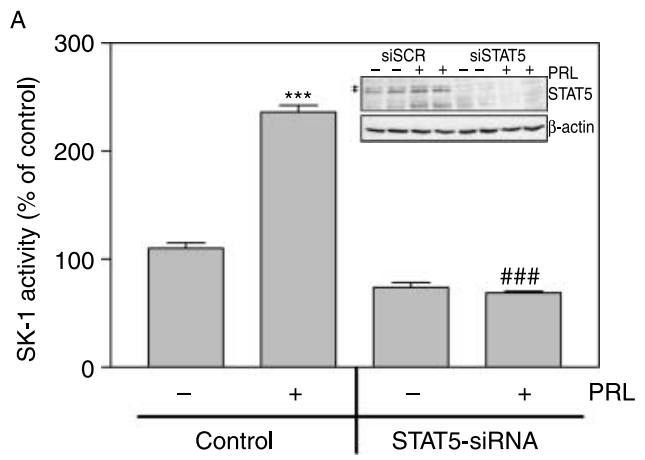

B

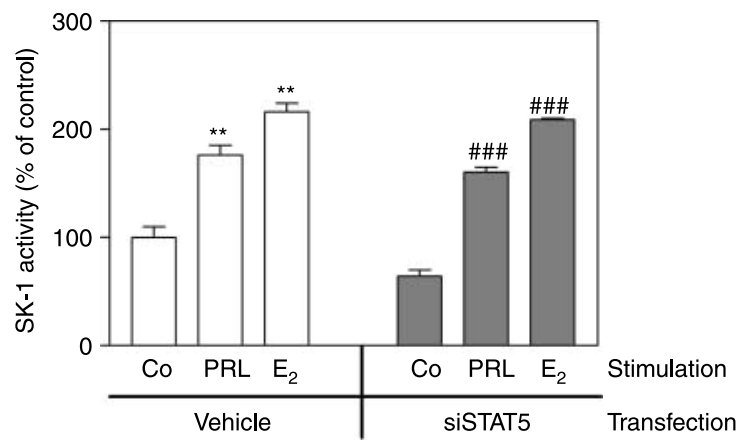

Figure 7 Effect of STAT5 depletion by siRNA transfection on prolactin-induced SK-1 activity in MCF7 cells. MCF7 cells were transfected with either vehicle (control) or siRNA of human STAT5 as described in the Materials and methods section. Thereafter, cells were rendered serum-free and stimulated for $24 \mathrm{~h}$ with either vehicle $(-)$ or $5 \mu \mathrm{g} / \mathrm{ml}$ prolactin $(\mathrm{PRL},+)(\mathrm{A})$, or (B) for $15 \mathrm{~min}$ with vehicle (Co), $5 \mu \mathrm{g} / \mathrm{ml}$ prolactin (PRL) or $10 \mathrm{nM}$ $17 \beta$-estradiol $\left(E_{2}\right)$. Cell extracts were taken either for SDSPAGE, protein transfer, and Western blot analysis of STAT5 (at a dilution of 1:250; inset) or for an SK-1 activity assay as described in the Materials and methods section. Results are expressed as percentage of control values and are means \pm s.D. $(n=3)$, ${ }^{* * \star} P<0.001$ when compared with unstimulated control values; ${ }^{\# \# \#} P<0.001$ when compared with the PRL-stimulated values.

PRL levels, no therapeutic benefit in breast cancer patients is seen by dopamine agonists (Bonneterre et al. 1988).

Besides PRL, the SK-1 and its product S1P have also been proposed to play a critical role in tumor development and growth. Thus, S1P is a potent mitogen for many cell types (Huwiler et al. 2000, Spiegel \& Milstien 2003). Furthermore, overexpression of SK-1 leads to a transformed phenotype of NIH 3T3 fibroblasts causing tumor formation in SCID mice (Xia et al. 2000). In addition, overexpression of SK-1 in MCF7 breast cancer cells causes enhanced proliferation, decreased apoptosis, and leads to larger tumors in nude mice in an estrogen-dependent manner (Sukocheva et al. 2003).

All these data made it very tempting to speculate on a relation between PRL and SK-1. The upregulation of

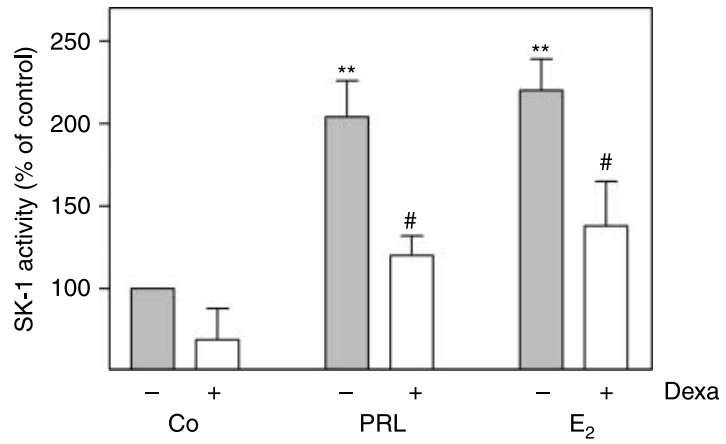

Figure 8 Effect of dexamethasone on prolactin- and $17 \beta$ estradiol-induced SK-1 activity in MCF7 cells. Confluent MCF7 cells were stimulated for $24 \mathrm{~h}$ with either vehicle (Co), $5 \mu \mathrm{g} / \mathrm{ml}$ prolactin (PRL), or $10 \mathrm{nM} 17 \beta$-estradiol $\left(E_{2}\right)$ in the absence $(-$, closed columns) or presence $(+$, open columns) of dexamethasone (Dexa, $100 \mathrm{nM}$ ). Cell extracts were taken for an in vitro SK-1 activity assay. Results are expressed as percentage of control values and are means \pm s.D. $(n=3)$, ${ }^{\star *} P<0.01$ when compared with unstimulated control values; ${ }^{\#} P<0.05$ when compared with the $P R L$ - or $E_{2}$-stimulated values respectively.

SK-1 by PRL reported in this study was shown to mechanistically involve an activation of the $S K-1$ gene promoter (Fig. 4). The human SK-1 promoter was first cloned by Nakade et al. (2003) and it was shown to be highly stimulated by the direct PKC activator TPA. The involvement of PKC in PRL-induced SK-1 upregulation is confirmed by the blocking effect of the selective PKC inhibitor Ro 318220 (Fig. 6A). In agreement with these findings, Marte et al. (1994) reported that PRL signaling involves PKC- $\alpha$ activation

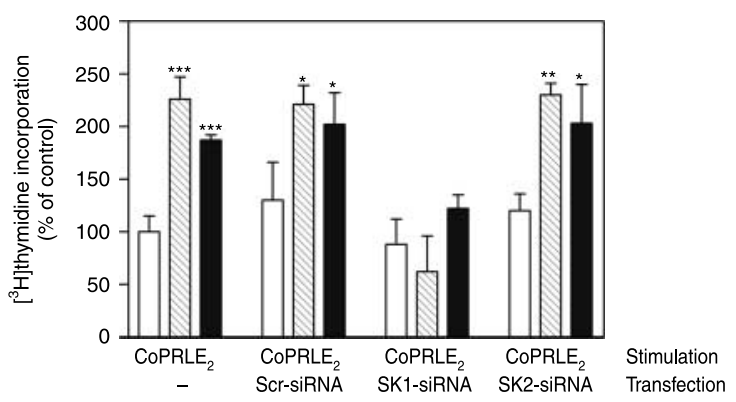

Figure 9 Effect of SK-1 and SK-2 depletion by siRNA transfections on prolactin and $17 \beta$-estradiol-induced proliferation of MCF7. MCF7 cells were either left untransfected $(-)$ or transfected with $200 \mathrm{nM}$ of a scrambled siRNA (Scr-siRNA), siRNA of human SK-1 (SK1-siRNA), or siRNA of human SK-2 (SK2-siRNA) as described in the Materials and methods section. Thereafter, cells were rendered serum-free for $48 \mathrm{~h}$ followed by a 24-h stimulation period with either vehicle (Co, open columns), prolactin (PRL; $5 \mu \mathrm{g} / \mathrm{ml}$, hatched columns), or $17 \beta$-estradiol ( $\mathrm{E}_{2} ; 10 \mathrm{nM}$; closed columns). Cell proliferation was determined as described in the Materials and methods section. Data are means \pm s.D. $(n=3),{ }^{\star} P<0.05$, ${ }^{\star \star} P<0.01$, ${ }^{\star \star \star} P<0.001$ when compared with the respective unstimulated control values. 


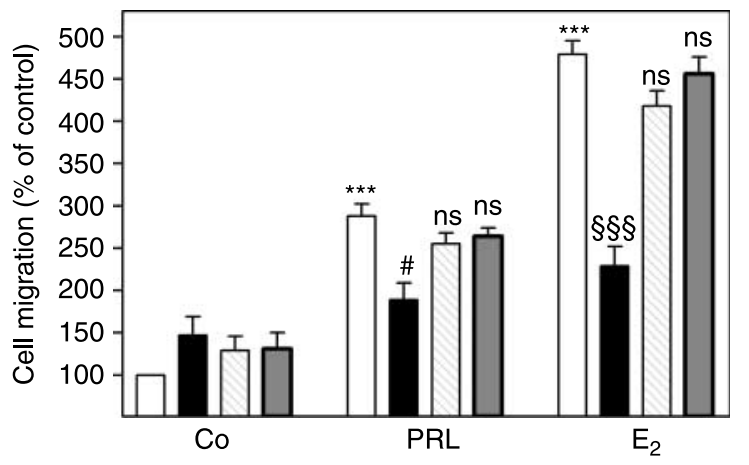

Figure 10 Effect of SK-1 and SK-2 depletion by siRNA transfection on prolactin- and $17 \beta$-estradiol-induced migration of MCF7. MCF7 cells were either left untransfected (open columns) or transfected with $200 \mathrm{nM}$ siRNA of human SK-1 (closed columns), human SK-2 (hatched columns), or a scrambled siRNA (gray columns) as described in the Materials and methods section. Thereafter, cells were rendered serumfree for $24 \mathrm{~h}$ and stimulated with either vehicle (Co), $5 \mu \mathrm{g} / \mathrm{ml}$ $\mathrm{PRL}$, or $10 \mathrm{nM} \mathrm{E}_{2}$ and allowed to migrate through $8 \mu \mathrm{M}$ membrane inserts for $24 \mathrm{~h}$. Data are means \pm s.D. $(n=3)$, ${ }^{* \star \star} P<0.001$ when compared with the unstimulated control values; ${ }^{\#} P<0.05$ when compared with the untransfected PRLstimulated values; ${ }^{\S \S} P<0.001$ when compared with the untransfected $\mathrm{E}_{2}$-stimulated values; ns, not significant when compared with the untransfected $\mathrm{PRL}$ or $\mathrm{E}_{2}$ values.

in the mouse mammary epithelial cells HC11. Similarly, Franklin et al. (2000) reported that PKC- $\alpha$ mediates PRL-stimulated aspartate aminotransferase expression in rat lateral prostate epithelial cells. On the other hand, Peters et al. (1999) reported that in a luteinized granulosa cell model, PRL receptor activation rather promotes activation of the PKC- $\delta$ isoenzyme. Which PKC isoenzyme is finally involved in PRL-triggered SK-1 upregulation in MCF7 cells cannot be concluded unequivocally from our data. However, the fact that staurosporine, which shows a high selectivity for the $\mathrm{Ca}^{2+}$-dependent PKC isoenzymes when compared with the $\mathrm{Ca}^{2+}$-independent PKC isoenzymes (Meyer et al. 1989), blocks PRLinduced SK-1 activity in the low nanomolar range (Fig. 6) rather favors the involvement of a $\mathrm{Ca}^{2+}$ dependent PKC isoenzyme, i.e. PKC- $\alpha$ which is the only $\mathrm{Ca}^{2+}$-dependent $\mathrm{PKC}$ isoenzyme expressed in MCF7 cells (Marino et al. 2001). An involvement of PKC- $\alpha$ in SK-1 mRNA upregulation and activation has also been shown for histamine-stimulated endothelial cells (Huwiler et al. 2006); thus, a general regulatory function of this PKC subtype in SK-1 expression may be envisioned.

Recently, Perks et al. (2004) reported that in MCF7 cells, PRL acts as a survival factor and protects cells from ceramide-induced apoptosis. However, they could not find a proliferative effect of PRL in MCF7
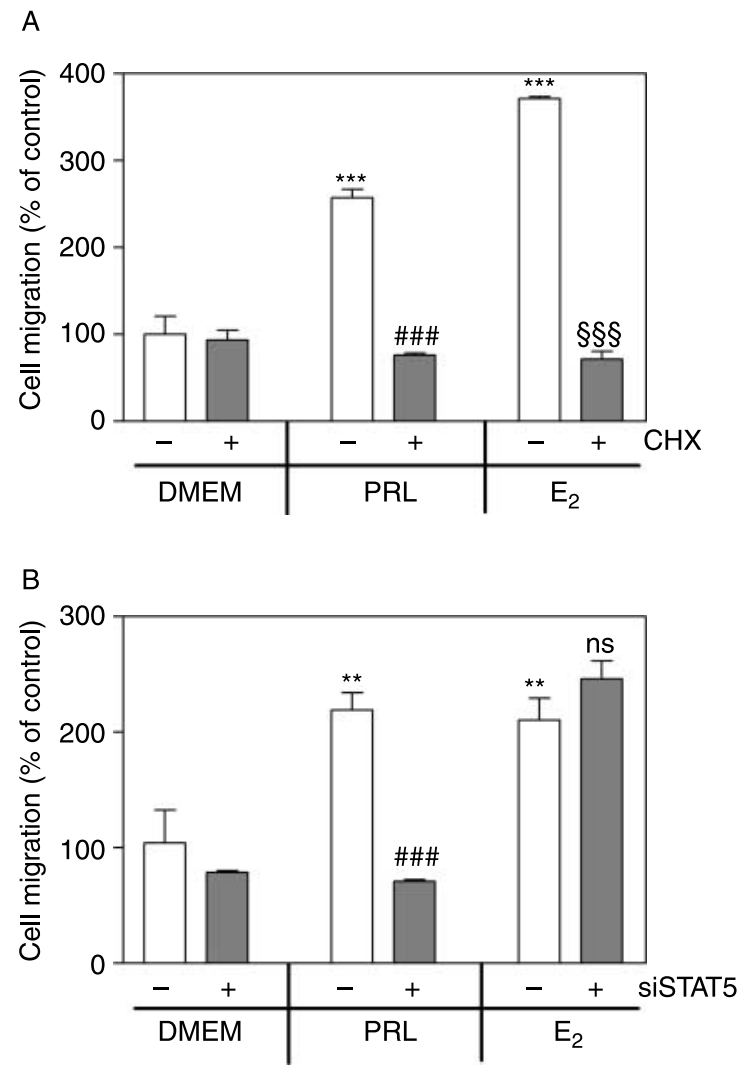

Figure 11 Effect of cycloheximide and STAT5 depletion on prolactin- and $17 \beta$-estradiol-induced migration of MCF7.

(A) MCF7 cells were stimulated for $24 \mathrm{~h}$ with either vehicle (DMEM), $5 \mu \mathrm{g} / \mathrm{ml}$ prolactin (PRL), or $10 \mathrm{nM} \mathrm{E}_{2}$ in the absence (open columns) or presence (closed columns) of $100 \mathrm{ng} / \mathrm{ml}$ cycloheximide. (B) MCF7 cells were transfected with either vehicle (open columns) or siRNA of human STAT5 (closed columns) prior to stimulated for $24 \mathrm{~h}$ with either vehicle (DMEM), $5 \mu \mathrm{g} / \mathrm{ml}$ prolactin (PRL), or $10 \mathrm{nM} \mathrm{E}_{2}$. Cells were allowed to migrate through $8 \mu \mathrm{M}$ membrane inserts for $24 \mathrm{~h}$. Data are means \pm S.D. $(n=3),{ }^{\star \star} P<0.01,{ }^{\star \star \star} P<0.001$ when compared with the unstimulated control values; ${ }^{\# \# ~} P<0.001$ when compared with the PRL-stimulated values; ${ }^{\S \S \S} P<0.001$ when compared with the $E_{2}$-stimulated values; ns, not significant when compared with the $\mathrm{E}_{2}$-stimulated values.

cells which contrasts to other reports in the same cell system (Bernard et al. 1991, Acosta et al. 2003; and our finding (Fig. 9)) and in vivo (Chen et al. 2002). Although the mechanism of this PRL-mediated cell protection was not further addressed, it is tempting to speculate that PRL stimulated S1P generation, which is a well-known anti-apoptotic factor and counterregulator of ceramide action (Hait et al. 2006).

Similar to PRL, two other mammogenic factors also activate SK-1 in the same biphasic manner in MCF7 cells, i.e. $\mathrm{E}_{2}$ (Sukocheva et al. 2003, 2006; and this study) and EGF (Döll et al. 2005). Interestingly, all three agonists act via different receptor classes. Whereas the PRL receptor (PRLR) belongs to the 
class of cytokine receptor superfamily and classically, but not exclusively couples to JAK/STAT, the EGF receptor belongs to the class of receptor tyrosine kinases and couples to various signaling devices including phospholipase $\mathrm{C}-\gamma$ and PI3K. $\mathrm{E}_{2}$ primarily acts through specific high-affinity ERs including $\alpha$ - and $\beta$-isoforms located within the cell nucleus. Although still controversial, many studies have shown an association of the PRLR with the ER receptor expression. Thus, PRLR and $E R \alpha$ are co-expressed in many breast tumors and PRL and $\mathrm{E}_{2}$ can cross-regulate their receptors in breast cancer cells (Shafie \& Brooks 1977, Ormandy et al. 1997, Gutzman et al. 2004a). Furthermore, it was reported that $\mathrm{E}_{2}$ contributes to tumor development by trans-activating the EGF receptor via S1P generation and $\mathrm{S}_{1} \mathrm{P}_{3}$ receptor activation (Sukocheva et al. 2006).

All the three mammogenic agonists cause not only SK-1 activation but also increased proliferation and migration of MCF7 cells and these cell responses depend critically on SK-1, but not on SK-2. This is based on the findings that selective depletion of SK-1, but not SK-2, by siRNA transfections reduces MCF7 proliferation and migration in response to all three agonists (Figs 9 and 10 of this study; Döll et al. 2005). Since all three agonists activate the $S K-1$ gene promoter, the question arises whether the same transcription factors are involved. SK-1 promoter analysis reveals the existence of several potential transcription factor-binding sites such as for Sp1, AP-1, AP-2, and AP-4. Recently, it was shown that PRL can activate AP-1 in breast cancer cells (Olazabal et al. 2000, Gutzman et al. 2004b), and also EGF is a wellknown activator of c-Jun and c-Fos which are the relevant constituents forming AP-1 (Manfroid et al. 2005). Moreover, $\mathrm{E}_{2}$ can stimulate the recruitment of $\mathrm{ER} \alpha$ and its cofactor p300 to the AP-1 site (Jeffy et al. 2005). In addition, an interaction of PRL and $\mathrm{E}_{2}$ was reported to cause an enhanced AP-1 activity by increasing MAPK/ ERK and c-Fos phosphorylation, and c-Fos promoter activity (Gutzman et al. 2004b, Gutzman 2005).

Furthermore, a critical involvement of the STAT5 transcription factor in PRL-induced SK-1 upregulation and activation became evident from this study (Fig. 7A). In this context, it has been extensively shown that PRL is an activator of the STAT5 transcription factor (Liu et al. 1995, Hynes et al. 1997) and that various $P R L$-regulated genes contain a STAT-binding site in their promoter sequences (Groner \& Gouilleux 1995). Sequence analysis of the SK-1 promoter indeed reveals such a putative STAT-binding site and future experiments will be needed to show whether this binding element is functional and able to bind STAT5.

Our data further suggest that especially the delayed second phase of SK-1 activation may be involved in the process of migration. This is stressed by the finding that either STAT5 depletion (Fig. 7) or incubation of cells in the presence of CHX (Fig. 5A) abolishes the delayed SK-1 activation as well as the migratory capacity of the cells (Fig. 11), whereas the acute PRLtriggered SK-1 activation still occurs.

Interestingly, PRL- and also $\mathrm{E}_{2}$-stimulated SK-1 upregulation is prevented by the glucocorticoid dexamethasone. The mechanism of this suppressive effect is presently unclear. However, various studies have provided evidence that glucocorticoids can interact with transcription factors such as $\mathrm{NF} \kappa \mathrm{B}$ and thus prevent its nuclear translocation. Furthermore, glucocorticoids can induce the NFKB-inhibitory

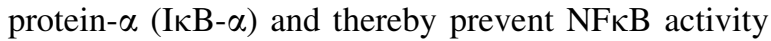
(Auphan et al. 1995). Indeed, a potential NFKB DNAbinding element is found in the $5^{\prime}$-flanking region of the human $S K-1$ gene although the functionality of this element still needs to be proven. In vivo glucocorticoids not only act as immunosuppressive and antiinflammatory agents but are also effective in the treatment of leukemia as they act as inducers of apoptosis (Distelhorst 2002). It is tempting to speculate that glucocorticoids promote apoptosis by suppressing SK-1 expression and activity and thereby reduce cellular S1P, which is considered not only a mitogenic factor but also an anti-apoptotic factor.

In summary, our data have shown that mammogenic hormones including PRL, estrogen, and EGF all induce SK-1 mRNA and protein expression via promoter activation which essentially contributes to increased cell proliferation and migration of breast cancer cells. Thus, the SK-1 may represent a novel and attractive pharmacological target to interfere with cancer cell growth and migration.

\section{Acknowledgements}

This work was financially supported by the Wilhelm Sander-Stiftung, the Swiss National Foundation (3100A0-111806), the German Research Foundation (FOG 784, GRK 757), the European Community (FP6: LSHM-CT-2004-005033), and the Novartis Foundation. The authors declare that there is no conflict of interest that would prejudice the impartiality of this scientific work.

\section{References}

Acosta JJ, Munoz RM, Gonzalez L, Subtil-Rodriguez A, Dominguez-Caceres MA, Garcia-Martinez JM, Calcabrini A, Lazaro-Trueba I \& Martin-Perez J 2003 Src mediates prolactin-dependent proliferation of T47D and 
MCF7 cells via the activation of focal adhesion kinase/Erk1/2 and phosphatidylinositol 3-kinase pathways. Molecular Endocrinology 17 2268-2282.

Alemany R, Sichelschmidt B, Meyer zu Heringdorf D, Lass H, van Koppen CJ \& Jakobs KH 2000 Stimulation of sphingosine-1-phosphate formation by the $\mathrm{P}_{2} \mathrm{Y}_{2}$ receptor in HL-60 cells: $\mathrm{Ca}^{2+}$ requirement and implication in receptor-mediated $\mathrm{Ca}^{2+}$ mobilization, but not MAP kinase activation. Molecular Pharmacology 58 491-497.

Auphan N, DiDonato JA, Rosette C, Helmberg A \& Karin M 1995 Immunosuppression by glucocorticoids: inhibition of NF $\mathrm{B}$ activity through induction of I $\mathrm{B}$ synthesis. Science 270 286-290.

Baumruker T, Bornancin F \& Billich A 2005 The role of sphingosine and ceramide kinases in inflammatory responses. Immunology Letters 96 175-185.

Bernard DJ, Maurizis JC, Sauvezie B, Bignon YJ, Chassagne J, Chollet P \& Plagne R 1991 Antagonism of prolactin binding by cyclosporine A on MCF7 breast tumour cell line. Anticancer Research 11 2147-2151.

Bonneterre J, Mauriac L, Weber B, Roche H, Fargeot P, Tuniana-Hulin M, Sevin M, Chollet P \& Cappelaere P 1988 Tamoxifen plus bromocriptine versus tamoxifen plus placebo in advanced breast cancer: results of a double blind multicentre clinical trial. European Journal of Cancer and Clinical Oncology 24 1851-1853.

Chen NY, Holle L, Li W, Peirce SK, Beck MT \& Chen WY 2002 In vivo studies of the anti-tumor effects of a human prolactin antagonist, hPRL-G129R. International Journal of Oncology 20 813-818.

Couse JF \& Korach KS 1999 Estrogen receptor null mice: what have we learned and where will they lead us? Endocrine Reviews 20 358-417.

Distelhorst CW 2002 Recent insights into the mechanism of glucocorticosteroid-induced apoptosis. Cell Death and Differentiation 9 6-19.

Döll F, Pfeilschifter J \& Huwiler A 2005 The epidermal growth factor stimulates sphingosine kinase-1 in the human mammary carcinoma cell line MCF7. Biochimica et Biophysica Acta 1738 72-81.

Franklin RB, Zou J, Ma J \& Costello LC 2000 Protein kinase $\mathrm{C}-\alpha,-\varepsilon$ and AP-1 mediate prolactin regulation of mitochondrial aspartate aminotransferase expression in the rat lateral prostate. Molecular and Cellular Endocrinology 170 153-161.

French KJ, Schrecengost RS, Lee BD, Zhuang Y, Smith SN, Eberly JL, Yun JK \& Smith CD 2003 Discovery and evaluation of inhibitors of human sphingosine kinase. Cancer Research 63 5962-5969.

Groner B \& Gouilleux F 1995 Prolactin-mediated gene activation in mammary epithelial cells. Current Opinion in Genetics and Development 5 587-594.

Gutzman JH 2005 PRL and EST enhance the activity of AP-1 in breast cancer cells: role of extracellularly regulated kinase 1/2-mediated signals to c-fos. Molecular Endocrinology 19 1765-1778.
Gutzman JH, Miller KK \& Schuler LA 2004a Endogenous hPRL and not exogenous hPRL induces ER $\alpha$ and PRLR expression and increases estrogen responsiveness in breast cancer cells. Journal of Steroid Biochemistry and Molecular Biology 88 69-77.

Gutzman JH, Rugowski DE, Schroeder MD, Watters JJ $\&$ Schuler LA 2004b Multiple kinase cascades mediate prolactin signals to activating protein-1 in breast cancer cells. Molecular Endocrinology 18 3064-3075.

Hait NC, Oskeritzian CA, Paugh SW, Milstien S \& Spiegel S 2006 Sphingosine kinases, sphingosine 1-phosphate, apoptosis and diseases. Biochimica et Biophysica Acta 1758 2016-2026.

Hla T 2003 Signaling and biological actions of sphingosine 1-phosphate. Pharmacological Research 47 401-407.

Huwiler A, Kolter T, Pfeilschifter J \& Sandhoff K 2000 Physiology and pathophysiology of sphingolipid metabolism and signaling. Biochimica et Biophysica Acta 1485 63-99.

Huwiler A, Döll F, Ren S, Klawitter S, Greening A, Römer I, Bubnova S, Reinsberg L \& Pfeilschifter J 2006 Histamine increases sphingosine kinase-1 expression and activity in the human arterial endothelial cell line EA.hy 926 by a PKC- $\alpha$-dependent mechanism. Biochimica et Biophysica Acta 1761 367-376.

Hynes NE, Cella N \& Wartmann M 1997 Prolactin mediated intracellular signaling in mammary epithelial cells. Journal of Mammary Gland Biology and Neoplasia 2 19-27.

Jeffy BD, Hockings JK, Kemp MQ, Morgan SS, Hager JA, Beliakoff J, Whitesell LJ, Bowden GT \& Romagnolo DF 2005 An estrogen receptor-alpha/p300 complex activates the BRCA-1 promoter at an AP-1 site that binds Jun/Fos transcription factors: repressive effects of p53 on BRCA-1 transcription. Neoplasia 7 873-882.

Jordan VC 2004 Selective estrogen receptor modulation: concept and consequences in cancer. Cancer Cell 5 207-221.

Kohama T, Olivera A, Edsall L, Nagiec MM, Dickson R \& Spiegel S 1998 Molecular cloning and functional characterization of murine sphingosine kinase. Journal of Biological Chemistry $27323722-23728$.

Liu X, Robinson GW, Gouilleux F, Groner B \& Hennighausen L 1995 Cloning and expression of Stat5 and an additional homologue (Stat5b) involved in prolactin signal transduction in mouse mammary tissue. PNAS 92 8831-8835.

Liu H, Sugiura M, Nava VE, Edsall LC, Kono K, Poulton S, Milstien S, Kohama T \& Spiegel S 2000 Molecular cloning and functional characterization of a novel mammalian sphingosine kinase type 2 isoform. Journal of Biological Chemistry 275 19513-19520.

Manfroid I, van de Weerdt C, Baudhuin A, Martial JA \& Müller M 2005 EGF stimulates Pit-1 independent transcription of the human prolactin pituitary promoter in 
human breast cancer SK-BR-3 cells through its proximal AP-1 response element. Molecular and Cellular Endocrinology 229 127-139.

Marino M, Distefano E, Caporali S, Ceracchi G, Pallottini V \& Trentalance A $2001 \beta$-estradiol stimulation of DNA synthesis requires different PKC isoforms in HepG2 and MCF7 cells. Journal of Cellular Physiology 188 170-177.

Marte BM, Meyer T, Stabel S, Standke GJ, Jaken S, Fabbro D \& Hynes NE 1994 Protein kinase C and mammary cell differentiation: involvement of protein kinase $\mathrm{C}-\alpha$ in the induction of $\beta$-casein expression. Cell Growth and Differentiation 5 239-247.

Meyer T, Regenass U, Fabbro D, Alteri E, Rösel J, Müller M, Caravatti G \& Matter A 1989 A derivative of staurosporine (CGP 41 251) shows selectivity for protein kinase $\mathrm{C}$ inhibition and in vitro anti-proliferative as well as in vivo anti-tumor activity. International Journal of Cancer 43 851-856.

Milstien S \& Spiegel S 2006 Targeting sphingosine-1phosphate: a novel avenue for cancer therapeutics. Cancer Cell 9 148-150.

Nakade Y, Banno Y, Koizumi KT, Hagiwara K, Sobue S, Koda M, Suzuki M, Kojima T, Takagi A, Asano H et al. 2003 Regulation of sphingosine kinase 1 gene expression by protein kinase $\mathrm{C}$ in a human leukemia cell line, MEG-01. Biochimica et Biophysica Acta 1635 104-116.

Nava VE, Hobson JP, Muthy S, Milstien S \& Spiegel S 2002 Sphingosine kinase type 1 promotes estrogen-dependent tumorigenesis of breast cancer MCF-7 cells. Experimental Cell Research 281 115-127.

Olazabal I, Munoz J, Ogueta S, Obregon E \& Garcia-Ruiz JP 2000 Prolactin (PRL)-receptor system increases cell proliferation involving JNK (c-Jun amino terminal kinase) and AP-1 activation: inhibition by glucocorticoids. Molecular Endocrinology 14 564-575.

Ormandy CJ, Hall RE, Manning DL, Robertson JFR, Blamey RW, Kelly PA, Nicholson RI \& Sutherland RL 1997 Coexpression and cross-regulation of the prolactin receptor and sex steroid hormone receptors in breast cancer. Journal of Clinical Endocrinology and Metabolism 82 3692-3699.

Ormandy CJ, Naylor M, Harris J, Roberstson F, Horseman ND, Lindeman GJ, Visvader J \& Kelly PA 2003 Investigation of the transcriptional changes underlying functional defects in the mammary glands of prolactin receptor knockout mice. Recent Progress in Hormone Research 58 297-323.

Perks CM, Keith AJ, Goodhew KL, Savage PB, Winters ZE \& Holly JM 2004 Prolactin acts as a potent survival factor for human breast cancer cell lines. British Journal of Cancer 91 305-311.

Peters CA, Maizels ET \& Hunzicker-Dunn M 1999 Activation of PKC $\delta$ in the rat corpus luteum during pregnancy. Potential role of prolactin signaling. Journal of Biological Chemistry 274 37499-37505.

Rose-Hellekant TA, Arendt LM, Schroeder MD, Gilchrist K, Sandgren EP \& Schuler LA 2003 Prolactin induces ER $\alpha$ positive and $\mathrm{ER} \alpha$-negative mammary cancer in transgenic mice. Oncogene 22 4664-4674.

Shafie S \& Brooks SC 1977 Effect of prolactin on growth and the estrogen receptor level of human breast cancer cells (MCF-7). Cancer Research 37 792-799.

Spiegel S \& Milstien S 2003 Sphingosine-1-phosphate: an enigmatic signalling lipid. Nature Reviews. Molecular Cell Biology 4 397-440.

Sukocheva OA, Wang L, Albanese N, Pitson SM, Vadas MA \& Xia P 2003 Sphingosine kinase transmits estrogen signaling in human breast cancer cells. Molecular Endocinology 17 2002-2012.

Sukocheva O, Wadham C, Holmes A, Albanese N, Verrier E, Feng F, Bernal A, Derian CK, Ullrich A, Vadas MA et al. 2006 Estrogen transactivates EGFR via the sphingosine 1-phosphate receptor Edg-3: the role of sphingosine kinase1. Journal of Cell Biology 173 301-310.

Tworoger SS \& Hankinson SE 2006 Prolactin and breast cancer risk. Cancer Letters 243 160-169.

Xia P, Gamble JR, Wang L, Pitson SM, Moretti PA, Wattenberg BW, Dándrea RJ \& Vadas MA 2000 An oncogenic role of sphingosine kinase. Current Biology 10 1527-1530. 